\title{
Adoption of Nutrient Management Practices in Rice Crop - A Study of Jammu and Kashmir, India
}

\author{
Uzma Rashid*, Sheikh Muzaffar Ahmad, Hilal Malik, Naqeeb Raja, \\ Dawood Yousuf and Irfat Rashid
}

\author{
Sher-e-Kashmir University of Agricultural Sciences and Technology of Kashmir, \\ Division of Agriculture Extension and Communication, Faculty of Agriculture, Wadoora, \\ Sopore - 193201, India \\ *Corresponding author
}

\begin{tabular}{|c|c|}
\hline & A B S T RAC \\
\hline Keywords & \multirow{3}{*}{$\begin{array}{l}\text { The study on level of adoption regarding nutrient management practices in rice crop } \\
\text { conducted during the year } 2016 \text { on a sample of } 160 \text { farmers drawn from eight randomly } \\
\text { selected villages of four randomly selected blocks of Baramulla district of Jammu and } \\
\text { Kashmir revealed that none of the respondents had applied the recommended dose/s of } \\
\text { SKUAST-Kashmir. A substantial percentage of the respondents had applied } 75-100 \text { per } \\
\text { cent of recommended dose/s of Urea }(58.13 \% \text {, ) DAP }(42.40 \%) \text { and MOP }(52.50 \%) \\
\text { respectively at last puddling. It was also found that } 51.25 \text { percent and } 40.62 \text { percent of } \\
\text { them had applied } 75-100 \text { per cent of } 1^{\text {st }} \text { and } 2^{\text {nd }} \text { top dressing of urea in the rice crop } \\
\text { respectively. It was further noticed that only } 36.88 \text { per cent respondents had applied } 50-75 \\
\text { percent of the recommended dose ZnSo }{ }_{4} \text { in rice crop. The data further revealed that a } \\
\text { majority of the respondents applied Urea, DAP and MOP at the recommended time. So far } \\
\text { as } 1^{\text {st }} \text { and } 2^{\text {nd }} \text { top dressing of Urea is concerned, almost half of the respondents applied it at } \\
\text { the right time in the rice crop. }\end{array}$} \\
\hline Article Info & \\
\hline & \\
\hline
\end{tabular}

\section{Introduction}

Rice is not only a staple food but also a source of livelihood for the people. In India, the crop is cultivated over an area of 42.65 million hectares with a production of 104.32 million tones and productivity of $2228 \mathrm{~kg} / \mathrm{ha}$ (Economic Survey 2013-14). Rice accounts for about 43 percent of total food grains production and 55 percent of cereals production of the country (FAOSTAT, 2013). Although area under rice in Kashmir accounts for about $0.27 \mathrm{~m}$ ha only, yet it plays a significant role in the state economy. The productivity (3.2MT/ha) in the valley is higher as compared to the National average productivity of about $1.9 \mathrm{MT} / \mathrm{ha}$ (Sharma et al., 2011). In Baramulla District of J\& K, the area under rice during the years 2011-12 to 2014-15 has increased from 8094 to 8514 hectares but the production during the said period has decreased from 194.39 to 144.39 thousand metric tonnes (Directorate of Economics \& Statistics, J\&K 2015-16). The imbalance use of nutrients has adversely affected soil health, nutrient reserve and ultimately the yield. The soil-test based fertilizer application along with judicious 
combination of chemical and organics for achieving enhanced and sustainable production is the need of the hour. Integrated use of organic manures and inorganic fertilizers is desirable for stability in production through maintaining the soil productivity and soil health. Keeping this in view the present study was undertaken with specific objective of determining the level of adoption of recommended nutrient management practices in rice crop.

\section{Materials and Methods}

The present study was conducted in Baramulla District of Jammu and Kashmir. Out of 26 development blocks in District Baramulla, four Development Blocks were selected randomly for the present study. Two villages were randomly selected from each of the four Development Blocks. List of rice growers in all the eight selected villages was prepared in consultation with the concerned Agriculture Extension Officers (AEOs), Junior Agriculture Assistants (JAAs), Village Agriculture Extension Assistants (VAEAs) and other extension functionaries.

Out of the list, 160 farmers were selected through Stratified Random Sampling technique. The size of the sample from each stratum was proportional to the number of farmers in it.

The data were collected through personal interview technique with the help of pre tested interview schedule. The data were digitized, processed and analyzed with frequencies and percentages.

\section{Results and Discussion}

The main findings of the study have been discussed as under:

\section{Adoption of FYM}

Majority of the respondents (40.62\%) had applied 75-100 per cent of the recommended dose of FYM, followed by 31.88 per cent who had applied 50-75 per cent of the recommended doses of FYM. The respondents who had applied below 50 per cent of recommended dose of FYM were 27.50 per cent (Table 1).

\section{Adoption of urea}

A perusal of the data in Table 2 reveals that majority of the respondents $(58.13 \%)$ had applied 75-100 per cent of the recommended basal dose of Urea at last puddling.

The data also revealed that 30.62 per cent of them applied 50-75 per cent of the basal dose of urea at last puddling and the remaining (11.25\%) applied below 50 percent of the recommended dose.

\section{Adoption of Diammonium Phosphate (DAP)}

A perusal of the data in Table 3 indicates that 42.50 percent of the respondents had applied $75-100$ per cent of recommended dose of DAP at last puddling followed by 33.12 per cent respondents who had applied 50-75 percent of the recommended dose of DAP at last puddling. However, those who were found to apply below 50 percent of recommended dose of DAP were 24.37 Percent only.

\section{Adoption of Muriate of Potash (MOP)}

It was noticed from Table 4 that a majority of the respondents $(52.50 \%)$ had applied 75-100 per cent of the recommended dose of MOP at last puddling, followed by 36.88 per cent who had applied 50-75 per cent of the recommended dose of MOP.

Only 10.62 per cent of the respondents were found to apply below 50 of the recommended dose of MOP at last puddling. 


\section{Adoption of first top dressing of urea}

The data presented in Table 5 reveals that majority of the respondents $(51.25 \%)$ had applied 75-100 per cent of the recommended dose of $1^{\text {st }}$ top dressing of Urea in the rice crop followed by 35.62 per cent respondents who had applied 50-75 per cent of the recommended dose of $1^{\text {st }}$ top dressing of urea. The data further revealed that only 13.13 per cent respondents had applied below 50 per cent dose of 1st top dressing of urea in the rice crop.

\section{Adoption of $2^{\text {nd }}$ top dressing of urea}

The data in Table 6 depicted that a substantial percentage of respondents (40.62\%) applied 75-100 per cent of the recommended $2^{\text {nd }}$ top dressing of Urea, followed by respondents (31.88\%) who had applied 50-75 per cent of the recommended $2^{\text {nd }}$ top dressing of urea. It was further revealed that only 27.50 percent respondents had applied below 50 percent of $2^{\text {nd }}$ top dressing of Urea in the rice.

\section{Adoption of zinc sulphate $\left(\mathrm{ZnSO}_{4}\right)$}

The data in Table 7 depicted that only 36.88 per cent respondents had applied $\mathrm{ZnSO}_{4}$ in rice crop. Out of which majority of the respondents (45.77\%) had applied 50-75 per cent of the recommended dose of $\mathrm{ZnSO}_{4}$ in rice crop, followed by 32.20 per cent respondents who had applied below 50 per cent of the recommended dose of $\mathrm{ZnSO}_{4}$. The data further reveals that only 22.03 per cent respondents had applied 75-100 per cent of the recommended dose of $\mathrm{ZnSO}_{4}$ in the rice crop.

\section{Adoption of time of application of fertilizers}

The data presented in Table 8 revealed that majority of the respondents applied Urea $(54.38 \%)$, DAP $(70.00 \%)$ and MOP $(58.75 \%)$ at the recommended time in the rice crop. Almost 50 per cent respondents applied $1^{\text {st }}$ and $2^{\text {nd }}$ top dressing of Urea at the recommended time in the rice crop.

Table.1 Distribution of respondents according to deviations from the recommended dose of FYM applied in rice $(n=160)$

\begin{tabular}{|c|c|c|c|}
\hline \multicolumn{2}{|r|}{ Dose of FYM applied } & $\begin{array}{l}\text { Number of } \\
\text { respondents }\end{array}$ & Percentage \\
\hline i) & $75-100 \%$ of recommended * & 65 & 40.62 \\
\hline ii) & $50-75 \%$ of recommended & 51 & 31.88 \\
\hline iii) & Below $50 \%$ of recommended & 44 & 27.50 \\
\hline
\end{tabular}

Table.2 Distribution of respondents according to deviations from the recommended dose of Urea applied in rice $(\mathrm{n}=160)$

\begin{tabular}{|c|c|c|c|}
\hline \multicolumn{2}{|r|}{ Dose of urea applied } & $\begin{array}{l}\text { Number of } \\
\text { respondents }\end{array}$ & Percentage \\
\hline i) & $75-100 \%$ of recommended $*$ & 93 & 58.13 \\
\hline ii) & $50-75 \%$ of recommended & 49 & 30.62 \\
\hline iii) & Below $50 \%$ of recommended & 18 & 11.25 \\
\hline
\end{tabular}


Table.3 Distribution of respondents according to deviations from the recommended dose of DAP applied in rice $(\mathrm{n}=160)$

\begin{tabular}{|c|c|c|c|}
\hline Dose of DAP applied & $\begin{array}{c}\text { Number of } \\
\text { respondents }\end{array}$ & Percentage \\
\hline i) & $\mathbf{7 5 - 1 0 0 \%}$ of recommended * & 68 & 42.50 \\
\hline ii) & $\mathbf{5 0 - 7 5 \%}$ of recommended & 53 & 33.13 \\
\hline iii) & Below $\mathbf{5 0 \%}$ of recommended & 39 & 24.37 \\
\hline & *Recommended Dose of DAP $=\mathbf{6 . 5} \mathrm{kg} / \mathrm{kanal}$ at last puddling \\
\hline
\end{tabular}

Table.4 Distribution of respondents according to deviations from the recommended dose of MOP applied in rice $(\mathrm{n}=160$

\begin{tabular}{|c|c|c|c|}
\hline \multicolumn{2}{|r|}{ Dose of Urea } & $\begin{array}{l}\text { Number of } \\
\text { respondents }\end{array}$ & Percentage \\
\hline i) & $75-100 \%$ of recommended * & 84 & 52.50 \\
\hline ii) & $50-75 \%$ of recommended & 59 & 36.88 \\
\hline iii) & Below $50 \%$ of recommended & 17 & 10.62 \\
\hline
\end{tabular}

Table.5 Distribution of respondents according to deviations from the recommended $1^{\text {st }}$ top dressing of urea applied in rice $(n=160)$

\begin{tabular}{|l|c|c|c|}
\hline & Dose of urea $\mathbf{1}^{\text {st }}$ top dressing & $\begin{array}{c}\text { Number of } \\
\text { respondents }\end{array}$ & Percentage \\
\hline i) & $\mathbf{7 5 - 1 0 0 \%}$ of recommended * & 82 & 51.25 \\
\hline ii) & $\mathbf{5 0 - 7 5 \%}$ of recommended & 57 & 35.62 \\
\hline iii) $\quad$ Below $\mathbf{5 0 \%}$ of recommended & 21 & 13.13 \\
\hline * Recommended $\mathbf{1}^{\text {st }}$ top dressing of urea $=\mathbf{3 . 2 5} \mathrm{kg} / \mathrm{kanal}$ & \\
\hline
\end{tabular}

Table.6 Distribution of respondents according to deviations from the recommended $2^{\text {nd }}$ top dressing of Urea applied in rice $(n=160)$

\begin{tabular}{|c|c|c|c|}
\hline \multicolumn{2}{|c|}{ Dose of fertilizer, urea $2^{\text {nd }}$ top dressing } & $\begin{array}{l}\text { Number of } \\
\text { respondents }\end{array}$ & Percentage \\
\hline i) & $75-100 \%$ of recommended $*$ & 65 & 40.62 \\
\hline ii) & $50-75 \%$ of recommended & 51 & 31.88 \\
\hline iii) & Below $50 \%$ of recommended & 44 & 27.50 \\
\hline
\end{tabular}


Table.7 Distribution of respondents according to deviations from the recommended dose of $\mathrm{ZnSO}_{4}$ applied in rice $(\mathrm{n}=59)$

\begin{tabular}{|c|c|c|c|}
\hline & Dose of $\mathrm{ZnSO}_{4}$ applied & $\begin{array}{l}\text { Number of } \\
\text { respondents }\end{array}$ & Percentage \\
\hline i) & $75-100 \%$ of recommended $*$ & 13 & 22.03 \\
\hline ii) & $50-75 \%$ of recommended & 27 & 45.77 \\
\hline iii) & Below $50 \%$ of recommended & 19 & 32.20 \\
\hline
\end{tabular}

Table.8 Distribution of respondents according to deviations from the recommended time of application of fertilizers applied in rice $(\mathrm{n}=160)$

\begin{tabular}{|c|c|c|c|c|c|c|c|c|c|c|}
\hline \multirow{3}{*}{$\begin{array}{c}\text { Time of } \\
\text { Application }\end{array}$} & \multicolumn{10}{|c|}{ Distribution of respondents according to time of application of fertilizers } \\
\hline & \multicolumn{2}{|c|}{ Urea } & \multicolumn{2}{|c|}{ DAP } & \multicolumn{2}{|c|}{ MOP } & \multicolumn{2}{|c|}{$\begin{array}{c}\text { Urea } 1^{\text {st }} \text { top } \\
\text { dressing }\end{array}$} & \multicolumn{2}{|c|}{$\begin{array}{c}\text { Urea } 2^{\text {nd }} \text { top } \\
\text { dressing }\end{array}$} \\
\hline & $\begin{array}{l}\text { No. of } \\
\text { farmers }\end{array}$ & $\begin{array}{c}\% \\
\text { Age }\end{array}$ & $\begin{array}{l}\text { No. of } \\
\text { farmers }\end{array}$ & $\begin{array}{c}\% \\
\text { age }\end{array}$ & $\begin{array}{l}\text { No. of } \\
\text { farmers }\end{array}$ & $\begin{array}{c}\% \\
\text { Age }\end{array}$ & $\begin{array}{c}\text { No. of } \\
\text { farmers }\end{array}$ & $\begin{array}{c}\% \\
\text { age }\end{array}$ & $\begin{array}{l}\text { No. of } \\
\text { farmers }\end{array}$ & $\begin{array}{c}\% \\
\text { Age }\end{array}$ \\
\hline $\begin{array}{l}\text { Recommend* } \\
\text { time }\end{array}$ & 87 & 54.38 & 112 & 70.00 & 94 & 58.75 & 76 & 47.50 & 82 & 51.25 \\
\hline $\begin{array}{l}\text { 3-5 days after } \\
\text { recommend } \\
\text { time }\end{array}$ & 73 & 45.62 & 48 & 30.00 & 66 & 41.25 & 84 & 52.50 & 78 & 48.75 \\
\hline
\end{tabular}

*Recommended time of application of chemical fertilizers Urea @4kgs/kanal; DAP @ $6.5 \mathrm{kgs} / \mathrm{kanal}$; MOP @ 2.5 $\mathrm{kgs} / \mathrm{kanal}$ to be applied at last puddling. $\mathrm{I}^{\text {st }}$ top dressing of Urea (Tillering stage) $=18-22$ days after transplanting $(\mathrm{DAT})$ and $2{ }^{\text {nd }}$ top dressing of Urea (Panicle Initiation stage) $=35-40$ DAT

The data further revealed that $45.62,30.00$ and 41.25 per cent respondents applied Urea, DAP and MOP 3-5 days after the recommended time in the rice crop respectively.

It is concluded while going through the data it has been observed that none of the respondents had applied the recommended doses of Urea, DAP, MOP, $\mathrm{ZnSO}_{4}$ and FYM in the rice crop. There is a dire need of educating farmers that the recommended doses of fertilizers and manures should be applied in the rice crop for obtaining the potential yields through awareness camps, training programmes and Kisan Goshtis which should be conducted prior to the sowing of rice. The farmers should be provided technical backstopping by conducting method demonstrations on seed treatment, planting of 2-3 seedlings/hill, line sowing and soil testing. The extension personnel should facilitate the organization of Farmers Field Schools (FFSs) in the villages and educate the fellow farmers regarding the application of fertilizers and manures at the critical stages of growth of rice crop. Besides, farmers need to be educated on the application of nutrients on soil test basis for getting the potential yields and saving of money in some cases. The farmers should be educated to apply chemical fertilizers and manures at the right time recommended by SKUAST-Kashmir for increasing the productivity. 


\section{References}

Directorate of Economics and Statistics 20152016 (url: http//agricoop.nic.in).

Economic Survey, Government of Jammu and Kashmir. 2013-14 (url: http//www.India environmentportal.org. in).

FAOSTAT, 2013. http://www. Faostat. fao. org/2013. Retrieved on 31st December, 2013.
Lal, R. 2011. Response of rice to integrated nutrient management, Climate change 65: 277-296.

Sharma, P. K., Sanjay, K., Sanjeev, K., Arvind, I., Suraj, P., Vishal, M. and Sudhir, J. 2011. Economic impact of front line demonstrations on cereals in Poonch district of Jammu \& Kashmir. Journal of Progressive Agriculture 2(1): 21.

\section{How to cite this article:}

Uzma Rashid, Sheikh Muzaffar Ahmad, Hilal Malik, Naqeeb Raja, Dawood Yousuf and Irfat Rashid. 2018. Adoption of Nutrient Management Practices in Rice Crop - A Study of Jammu \& Kashmir, India. Int.J.Curr.Microbiol.App.Sci. 7(12): 3183-3188.

doi: https://doi.org/10.20546/ijcmas.2018.712.367 